\title{
Human Conscience in Walter de la Mare's The Listeners: an Allegorical Exploration
}

\author{
Talha Yousaf $^{1}$, Khair Ul Bashar ${ }^{2}$ \\ ${ }^{1}$ Lecturer in English, Dept. of English, Abasyn University Peshawar, Pakistan \\ ${ }^{2}$ Lecturer in English, Dept. of English, Abasyn University Peshawar, Pakistan
}

\begin{tabular}{|c|c|}
\hline Article Info & Abstract \\
\hline Article history: & Purpose: This paper presents an allegorical exploration of Walter de la \\
\hline Received 05 September 2020 & Mare's The Listeners. It dwells on the presentation of the human conscience \\
\hline Revised 18 November 2020 & in the poem. \\
\hline Accepted 21 November 2020 & $\begin{array}{l}\text { Methodology/Approach: A literary analysis with focus on allegory. } \\
\text { Findings: The Listeners by Walter De La Mare is a poem built on }\end{array}$ \\
\hline $\begin{array}{l}\text { Keywords: } \\
\text { The Traveler, The Listeners, } \\
\text { Allegory, Human Conscience }\end{array}$ & $\begin{array}{l}\text { controversial grounds. The claimers have their own ambiguous theories. } \\
\text { Some explored it for musical aspects other for gothic elements. The } \\
\text { allegorical aspect of the poem is ignored not that they deny it, but because it } \\
\text { has many meanings to give. Apart from the eerie effects, the character of }\end{array}$ \\
\hline $\begin{array}{l}\text { Paper Type: } \\
\text { Research Article }\end{array}$ & $\begin{array}{l}\text { "The Traveler" and "Phantom Listeners" arise questions and suggestions. } \\
\text { The nearest meaning these characters attract is towards a human being. }\end{array}$ \\
\hline $\begin{array}{l}\text { Corresponding Author: } \\
\text { Khair UI Bashar } \\
\text { Email: } \\
\text { khairul.bashar@abasyn.edu.pk } \\
\end{array}$ & $\begin{array}{l}\text { Struggles between vice and virtue; and the inner evil and restless conscience } \\
\text { within. } \\
\text { Conclusion: The Traveller resembles human conscience more than any } \\
\text { other meaning given to it before. The consistence visits the terrified and un- } \\
\text { answering hosts, the reminding of a promise, the sudden and hard smites, } \\
\text { the lifting of head and making him (God) witness and the sad retrieval drags } \\
\text { us to one meaning only. }\end{array}$ \\
\hline
\end{tabular}

\section{Introduction}

Traditionally, allegory is considered as an art work that has symbolic and figurative meaning. Scholars in many periods maintain and let the allegory flourish in peculiar movements of history, particularly in middle ages. The limit of allegory is not confined, but it emerges in patterns of everyday's life and connects people mundane actions to larger symbolic themes (Csábi 16).

The theme of allegory can be found anywhere, not limited to big paragraphs or long poems only. A single sentence gives hidden direction like, "Don't judge a book by its cover", "The early bird catches the worm"," Its best to let the sleeping dog lie", each and every line shows different meaning on surface but to thinking and reasonable minds the meaning extends to far beyond letting the dog lie, judging books and capturing worm in early morning. The singular appearances of these lines tap into complex and deep knowledge that guides readers, and teach them how to act in different contexts. Many allegories convey moral messages. The term for such allegory is mini-allegory, for they are short and tiny containing the treasure of meaningful knowledge (Csábi 23). Allegory is not a single way process but a diversion. It can work through pictorial images, icons, written texts, and particularly in any form of discourse, from advertising slogans to artworks and political speeches. 
We all are cognizant of typical mobilization of allegories in narrative writing, where the lives of particular persons are presented as imaging the basic moment or the destiny of a group through which the genesis of past is taken as a disguised description of current dilemmas (Miller and Stam 44).

Allegory un-wraps the truth of the world far more than the disappearing glimpses of completeness gained in symbols. It always lays so bold claim towards the point and the truth. The truth exists beneath and the goal is to see it behind the thick curtain of the author's creation. If the truth is accessible, the allegory could not exist. As it is a mode response to human's state of being expelled from the truth it would accept (Cowan 110). The art of allegory is encoded by the author and demand the decode ignition form us. A poet, for example, plants allegorical effects by using specific techniques designed to be detected by the curious readers who share his/her cultural history (Miller and Stam 48).

The art of allegory is encoded by the author and demands the decoding process from the readers. A poet for example, plants allegorical effects by using specific techniques designed to be detected by the curious readers who share his/her cultural and moral history. There exists certain "intangibles" in our life on which we are entirely agreed; only allegory can fix it. However, the prevailing opinion is that allegory not an extended metaphor or in simple words rhetorical figure that can be applied on something "Cannot be said" or "so well said", in literary speech (Csábi 32).

The Listeners by Walter de la Mare was published in 1912 in his second collection of poetry. It is still one of his known piece of writing, ruminating the author's enthrallment with mystery and the supernatural. The poem came out as an enigma for the people and the critics chewed it well. The mysterious nature of the poem attracted the readers, the loyalty of traveller impressed them, the indifference of the listener's disgust them, the calling of traveller overwhelmed them, the horror of forest terrified them, and the departure of traveller left them sad and prisoners to anxiety. The poem attracted and left the readers puzzled and unravelled in different ways (Bentinck 33).

Gwynn \& Condee (1954) believe that it is not impossible to find allegorical meaning for the characters in the poem, particularly, the Traveller and Listeners but the variety that can be found for these characters (Bentinck 33). Readers have seen "The Traveller" as the Holy Ghost, Christ, a ghost, a man, God or Walter himself; the Listeners on the other hand have been considered as power of darkness, the dead, men, a living house hold, the riddle of life that needs to be solved or Walter's schoolmates. The suggestions received at that time are based on completely nothing. Confusion prevails for who is who in the poem. Most of them ignored the allegorical aspect with a view and believe Traveller to be human being and Listeners to be "Phantoms" (Bentinck 34).

De la Mare's Traveller, Robert Browning's Knight in "Childe Roland to the dark tower Cane", and Spencer's "Knight" in "Faerie Queen" are deserved heroes in the inn of literature. These heroes depict un-imaginable courage. In honouring their vows, they can cross any limit. In his poetry Walter de la Mare tried to capture the sensational feeling of faraway conscience which according to him comes easily to children, so the men could for once more try and revisit to the imaginative appearance they once possessed. 
The Theme of The Listeners is ambiguous, leaving the poem open to various interpretations. The poem opens with an anonymous "Traveller" who happens to arrive from nowhere into somewhere. Everything seems mysterious and questionable, the moonlight, the house, and the forest. The ferny floor creates an eerie effect and enhances something sinister. The gothic element comes when he mentions the phantom listeners. Walter dexterously uses dramatic irony to create breath taking suspense. The suspense touches climax when the Traveller knocks repeatedly at the door and the listeners choose to remain listeners only. With every knock, the temper of the Traveller increases along with his complaining voice. Hence, the Traveller leaves the scene by claiming the fulfilment of the promise.

The departure of the Traveller leaves the poem open for various interpretations and questions: who is the traveller? What is the promise? And who are the ghosts? These questions give the poem an eerie effect and de la Mare gets credited for it but still the questions remain unanswered.

\section{Methodology/Approach}

This study locates the meaning of a poem The Listeners through allegorical perspectives. There are four techniques through which allegorical meanings are obtained from the structure of a poem:

i. Text: The textual nature of allegorical meaning that uncover like a chain of paronomasia narration, associated with each other.

ii. Pretext: It unfolds the source (poem) which always set up outside the allegorical narratives, thus befit to the key interpretation.

iii. Context: The context of the poem addresses the question of formal evolution by pursuing the cultural causes of allegory. Since all allegories of a single source may differ in subsequent ages, depending upon the linguistic assumption on particular period.

iv. Reader: Reader is the last focus of allegory. Any allegory would develop into real action when the reader reads the text adequately. Besides from the other genres, allegory appeals to the reader as a system of sign having "signifier" and "signified" which discern their innermost features: as a reader shaped by the language.

Considering that the primary characteristic of allegory as a genre is to separate the representation meaning from the inner and implied meaning, a mode of analysis for allegory can rely on hermeneutics (Myers and Avison 38). Hermeneutics has been fundamentally involved in the locus of the meaning and present approaches to interpret it. The present research employs "hermeneutic circle" approach which deals with the dialectic between the comprehension of the poem as a whole (theory) and interpretation of its details (single word). These dialectic dimensions assist in decoding the concealed meaning from the apparent meaning of the poem. 


\section{Analysis and Results}

On $7^{\text {th }}$ February 1944 Walter De La Mare writes to Miss J. G. Sime, About "The Listeners":

I have repeatedly asked to unveil the true meaning behind the characters, and purpose they serve. It concerns me a bit now that what was really the intended meaning, It is meant from those particular lines, its principles, to me the Traveller is may be a reincarnation, revisiting figure to the world under a full moon and demanding answer for the same unanswerable question from the inhabitants of the house over and over again. The meaning is infinite and depends on the thinking of men. For it can't prove a poem, it proves the reads. (Bentinck 35 )

The front line symbols of Walter's poems and prose, particularly The Listeners, The ghost, The garden, The Traveller reveals that the creator is not worrying with death but with Conscience. Unlike the allegorical sketch of Spencer and his hero who brings evil to submission by force, the hero of Walter is gentle and promise keeper. The knight of Spencer kills the evils, takes a blood bath and gets deceived by its enemy. (Spencer, 1590). The rider of Walter comes out of duty and promises to deliver a message to the rude dwellers of the deserted house. The rider is the controversial figure giving birth to too many sketches and meanings in the mind of readers and critics. He is considered to be the holy ghost, Christ, a man, God or Walter himself. The table seems to be open for more assumptions that can occur in the future.

The theory of comparing The Traveller to the God seems to be rushed one. God is superior to all and answers to known. Describing him as a ghost is not fitting as the author made him speaker towards some phantom listeners. Saying that the Traveller is just a man bitters the curiosity we experience while reading the poem. The gut feeling says otherwise.

Is there anybody there?' said the Traveller

Where he stood perplexed and still

Tell them I came, and no one answered,

The Traveller experiences three stages in the poem. Firstly, when he arrives at the unholy place in expectation of answers, nobody knows what they might be. He calls out but gets silence in return. Secondly, when he receives a return blow of indifference from the creatures of the house, he stands astonished and perplexed. The Traveller arrives to fill a responsibility and is liable for the consequences of it but the cruelty of "The Listeners" fails him. Thirdly, it is when he turns to his sender and makes him (God) witness on the scene and situation of his failure and promise keeping. "There is more to it that meets the eye", failure and success are two faces of the same coin. Hard work is not always the way to achieve success and passiveness is not always the cause of failure, sometimes fate also intervene. The same is the case with "The Traveller". He performs his duty, takes the risk, puts all his efforts yet returns empty-handed. Human conscience shares the same fate, it is always around, often tries to correct us, and most of the time remains perplexed and disappointed. It is not the conscience that does not try but the inner self that does not respond. The inner good 
is like a fragile bird. It is happy when free, sad and terrified when imprisoned by the evil inside us. Conscience guides it till it is free, and ties to reach it once it is drowning in the hands of evil. Once it is lost to evil, the conscience returns empty hands every time.

Stood listening in the quiet of the moonlight

Hearkening in air stirred and shaken

Never the least stir made the listeners

The part played by "The listeners" is cruel but pitiable. Walter portrays them in a deserted haunted house, the prisoner hosts of the lonely house in the middle of a mysterious forest. The actions they do are under the whip of an unseen evil. The present influence of that power holds them captive inside and un-responsive to the world of men. The inner good in them is so corrupted that the cry from the Traveller makes them tremble and terrified. They know the authenticity of the message but the temporary hold of negative influence seals their tongues and makes them sinners. Human conscience faces the same resistance; it cries out the goodness and receives unresponsiveness of the inner, enslaved by evil desires. We all are cognizant of the wrong we do, the misguided we are yet we don't want to be saved by the Traveller. As we know he will come around, we have now to stay in the comfort of negativity, evil, wrong and chaos. In the process, human beings forget that once handed over to temporary desires they will be enslaved permanently. The frequent visits of conscience (Traveller) will one day stop or may continue but we might be far removed from its reach or saving.

Walter's worry is not of death but the Conscience. This opens another possibility and quite convincing meaning for the character of "The Traveller". The Era in which he wrote the poem was the period of conscience awakening. Labours revolted as they feared the wages are not enough anymore. Suffragettes started attacking the shops and later on pillar boxes. The strike and efforts of miners brought them the deal of minimum wages that year. All those events might have forced the pen of Walter towards the existence of conscience and its roll in human life. The Traveller resembles human conscience more than any other meaning to it given before. The consistence visits, the terrified and un-answering hosts, the reminding of a promise, the sudden and hard smites, the lifting of head and making him (God) witness and the sad retrieval drags us to one meaning only. The listeners are cruel, closing their eyes to light and ears to positivity so is the case with humans the goodness in us is so much suppressed by the evil that it never let the conscience trying of reaching to triumph. The good enslaved by evil never escapes until the power of conscience intervenes. The more it stays slave, the weaker it becomes and a time comes when seeing the difference fades into merge. The passive listeners are the hidden good and the strange traveller is the Conscience who has come to wake it up. Apart from this explanation every other prediction seems a mistaken hunch.

\section{Conclusion}

Poetry is not in words; it is your reactions to them. Allegory is created to address the keen readers; they hear one thing and understand other. Like the puzzle, the reader digs for 
reality. The problem lies when the idea is misinterpreted and leads the folk astray. The Listeners by Walter de la Mare faced the same flaw. The confession of the author "it concerns me a bit now that what was really the intended meaning", has left the poem opened for critics and readers to explore more. Yet a clue is found when it is said that the Creator is not worried about death but about conscience. This statement narrows down the search to a single meaning and that is human conscience. If the author intended to awaken the conscience and trigger it to dominate the evil inside, the Traveller is the living image of the same idea, trying to communicate with the evil inside.

\section{Conflict of Interest}

None

\section{Funding}

None

\section{Works Cited}

Morris, William. American heritage dictionary of the English language. American heritage, 1969.

Bentinck, A. "de la Mare's the Listeners." The Explicator 50.1 (1991): 33-35.

Cowan, Bainard. "Walter Benjamin's theory of allegory." New German Critique, vol.22, 1981, pp.109-122. https://doi.org/10.2307/487866

Csábi, Szilvia, ed. Expressive minds and artistic creations: studies in cognitive poetics. Oxford University Press, 2018.

Harper, Collins. "Collins English Dictionary-Complete and Unabridged." Режим доступу: http://www. thefreedictionary. com/freedom.-Дата звернення 23, 2003, pp.2012.

Golder, Harold. "Browning's Childe Roland." Publications of the Modern Language Association of America, 1924, pp. 963-978.

Ferguson, DeLancey. "DE LA MARE, The Listeners." Explicator, vol. 4, 1945.

De la Mare, Walter. The Listeners, and Other Poems. Constable, Limited, 1919.

Miller, Toby, and Robert Stam, eds. A companion to film theory. John Wiley \& Sons, 2004.

Milner, Evan. "'Is There Anybody There?': Solitude and the Hermeneutics of Love in the

Writings of Walter de la Mare." Journal of Language, Literature and Culture, vol.65, no.1, 2018, pp.50-59. https://doi.org/10.1080/20512856.2018.1443633

Myers, Michael D., and David Avison, eds. Qualitative research in information systems: a reader. Sage, 2002.

Roberts, W. Wright. "Walter de la Mare, the Listener." Music \& Letters, vol.16, no.2, 1935, pp. 128-136. https://www.jstor.org/stable/727349

Sutton, Julie P. "“The Pause That Follows": Silence, Improvised Music and Music

Therapy." Nordic Journal of Music Therapy, vol.,11, no.1,2002, pp. 27-38. https://doi.org/10.1080/08098130209478040

Warton, Thomas. Spenser's Faerie Queene: Letters on chivalry and romance. Taylor \& Francis, 2001. 